\title{
Common Ownership and Product Market Competition: Evidence from the U.S. Airline Industry
}

\author{
Alex Haerang Park ${ }^{* *}$, Ph.D Student, Seoul National University \\ Kyoungwon Seo, Associate Professor, Seoul National University
}

\begin{abstract}
$<$ Abstract $>$
We study how common ownership in a financial market can affect competition in product markets. We adopt a structural demand and supply model and use additional instrumental variables to overcome endogeneity problems. We then analyze data from the U.S. airline industry. We find that common ownership raised airfare prices and softened the competition between airline companies. Firms with higher common ownership linkage are more likely to internalize their price effects on the competitors' profits and thus coordinate on prices to a larger degree.
\end{abstract}

Keywords: Common Ownership; Overlapping Shareholders; Market Competition; Airline Industry; Structural Estimation

JEL Classification: G19, D49

* We thank Einar Kjenstad and two anonymous referees for their helpful comments. Seo gratefully acknowledges financial support from the Institute of Finance and Banking at Seoul National University.

** Corresponding Author. Address: Department of Economics, Seoul National University, 1, Gwanak-ro, Gwanak-gu, Seoul, Korea 08826; E-mail: widhpl@gmail.com; Tel: +82-2-880-6360; Fax: +82-2-875-8860.

Received: May 30, 2019; Revised: August 25, 2019; Accepted: August 29, 2019 


\section{기업간 공동 지배주주와 상품시장 경쟁: 미국 항공산업에 대한 실증분석*}

박 해 랑 (서울대학교 대학원생 $)^{* *}$

서 경 원 (서울대학교 부교수)

본 연구는 기업간 공동주주(common ownership)가 상품시장 경쟁에 미치는 영향이 있는지 검증 한다. 기존의 내생성 문제를 해결하기 위해 수요·공급 구조모형 및 도구변수를 도입하고 미국 항공 산업 데이터를 분석하였다. 실증분석 결과, 공동주주는 항공권 가격을 높이고 항공사간 경쟁을 저하 시키는 것으로 나타났다. 따라서 주주가 경쟁기업의 지분을 많이 가지고 있으면 해당기업은 다른 기업의 이익에 미치는 가격효과를 내재화하는 것으로 보인다.

핵심 단어: 기업간 공동주주(common ownership), 중첩(overlapping) 주주, 시장경쟁, 항공산업, 구조모형 추정

JEL 분류기호: G19, D49

* 본 논문은 서울대학교 증권금융연구소의 지원을 받은 연구임.

** 연락담당 저자, 주소: 서울특별시 관악구 관악로 1 사회과학대학 경제학부 08826; E-mail:widhpl@gmail.com; Tel: 02-880-6360; Fax: 02-875-8860. 


\section{Introduction}

In this paper, we study the effect of common ownership in the financial market on the competition in product markets. We adopt a structural model of demand and supply, which is a version of the model proposed by Berry et al. (1995) (BLP hereafter), to overcome the endogeneity problems related to market variables determined in equilibrium. Data on the U.S. airline industry are analyzed. We find that common ownership raised airfare prices, which consequently softened the competition among airline companies in the first quarter of 2009.

Common ownership refers to overlapping shareholders among companies within the same industry, which may weaken market competition when firms maximize the value of shareholders. For example, suppose investors hold shares of two competing firms. If one firm cuts its price to draw in more demand, the other loses its market share and the average market price decreases. This price competition reduces the other's profit and its firm value. The total value of the firms is maximized when the two firms act like a monopolist. Accordingly, shareholders with common ownership are more likely to vote against a business strategy that promotes competition among firms, which decreases the corporate incentive to compete. $<$ Figure $1>$ shows a growing level of common ownership in the U.S. airline industry. The average common

\section{〈Figure 1〉 Average Common Ownership}

We use the terms in (2) to measure the level of common ownership in the U.S. airline industry. This rising pattern can also be observed when the alternative measure, MHHI delta, is used. See Azar et al. (2018a).

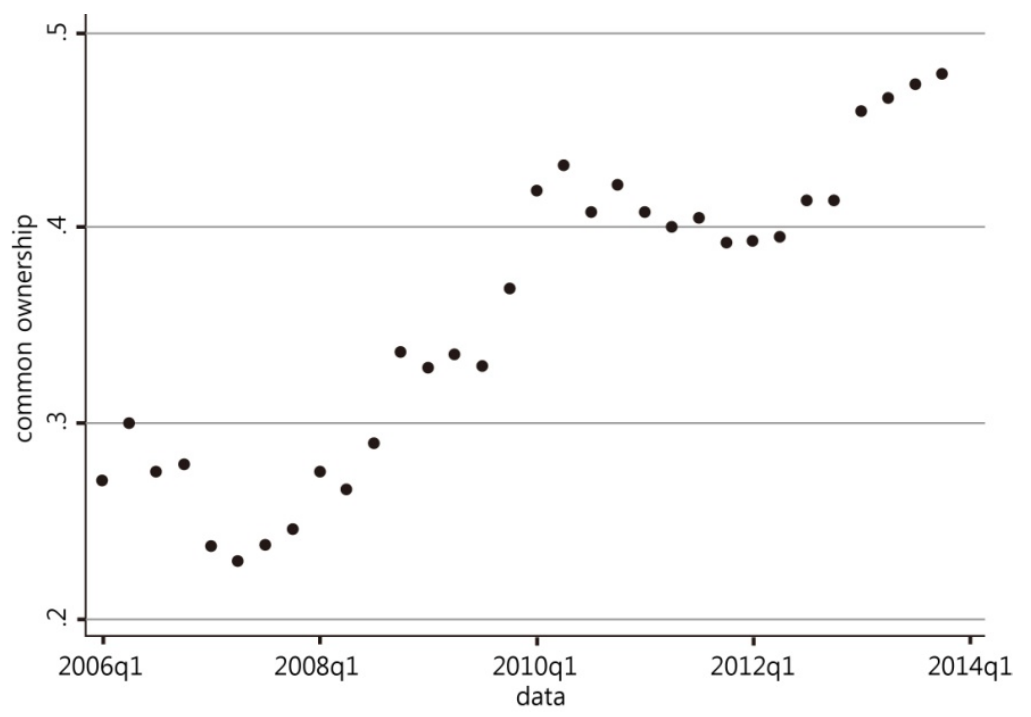


ownership has almost doubled from 2006 to 2013. With the recent popularity of passive investments and mergers and acquisitions movements in the asset management industry, the level of common ownership is expected to grow in the future and this growth could have a substantial effect on product market competition.

Studying the effect of common ownership on product markets involves the issue of endogeneity. In the recent empirical research that has spurred the current debate on common ownership, Azar et al. (2018a), MHHI delta is employed as a proxy variable of common ownership concentration. However, this measure depends on both common ownership and market shares, and factors related to market shares are likely to be correlated with unobservables that affect prices. If there is a cost-push factor left in error terms, price increases and market share decreases simultaneously, which in turn changes the MHHI delta. Furthermore, common ownership might be also endogenous in that a change in product prices could alter shareholdings. Therefore, this possible endogeneity problem could bias the estimate of the coefficient on MHHI delta, thereby misrepresenting the relationship between common ownership and product market competition. In this context, some have criticized the regression model of prices on MHHI delta and demanded a more theoretically motivated analysis (e.g., O'Brien and Waehrer, 2017; Backus et al., 2018).

We adopt a structural model approach to address the endogeneity problem by modeling demand and supply. Demand is assumed to follow a discrete-type randomcoefficient nested logit model that has been applied in several studies on the U.S. airline industry (e.g., Berry et al., 2006; Berry and Jia, 2010; Ciliberto and Williams, 2014). In addition, supply is modeled to incorporate the full ownership structure of shareholders and reflect the corporate incentive to coordinate on prices with competitors because of common ownership. From a firm's profit maximization problem, we derive the terms that mirror the anticompetitive incentive caused by common ownership. Along with demand and cost parameters, we estimate the coefficient of the common ownership terms, which reveals the relationship between common ownership and product market competition. The theory-driven common ownership terms do not depend on market shares, thereby reducing the endogeneity problem caused by the MHHI delta. We use the information on index inclusion to construct an instrumental variable of common ownership and address the remaining endogeneity.

The U.S. airline industry data in the first quarter of 2009 are used for our analysis. We choose the U.S. airline industry to study the effect of common ownership on the competition for the following reasons. First, the industry has gained attention over its possible anticompetitive outcomes. In recent years, the level of common ownership in the industry has almost doubled while there have been a governmental investiga- 
tion and a class-action lawsuit against major U.S. airlines over price collusion. ${ }^{1)}$ Second, the available industry database provides detailed information on productlevel characteristics and shows large variations across markets, which helps identify parameters. Our sample dataset has 244,253 observations and 5,503 markets. We define a market as a unidirectional trip between two airports.

Our empirical analysis shows that common ownership has softened competition among airline companies in the first quarter of 2009. The coefficient on common ownership is significantly positive, rejecting the null hypothesis that common ownership does not affect a firm's pricing behavior in product markets. The significantly positive coefficient on common ownership means airline companies are controlled by voting shareholders that care about their interests in other competitors because of commonly held shares. This result implies that airline companies internalize their price effects on others' profits and coordinate price setting. The degree of internalization and price coordination depends on the pairwise level of common ownership between firms. Firms tend to act more collusively as the common ownership linkage becomes stronger. The estimation results on all other parameters in the structural model of demand and supply are consistent with those of the previous literature on the airline industry Berry et al. (2006), Berry and Jia (2010), Ciliberto and Williams (2014).

Our study contributes to the ongoing discussions on the anticompetitive effect of common ownership. The theoretical literature argues that firms seek to maximize the industry profit and act collusively when shareholders have diversified portfolio (e.g., Rotemberg, 1984; Hansen and Lott, 1996; Azar, 2017). On the empirical side, however, the evidence is diverging. Some studies have found that common ownership leads to more product-market collaborations, such as joint ventures and strategic alliances (He and Huang, 2017) and higher prices (Azar et al., 2018a, 2016) while others have found mixed and economically insignificant (Gramlich and Grundl, 2017) or no evidence (Kennedy et al., 2017). Our model is the closest to Kennedy et al. (2017). However, we reached a different conclusion, which may be due to the differences in the dataset, demand model, and control variables. We construct our dataset by following Berry and Jia (2010) and allow for heterogeneous taste between business travelers

1) The Department of Justice (DOJ) launched an antitrust investigation against the four largest U.S. airlines in July 2015 (McLaughlin and Schlangenstein, 2015a), and at the time multiple consumer lawsuits were filed against them, which have been consolidated into In re: Domestic Airline Travel Ticket Litigation, Case 1:15-mc-01404-CKK. The DOJ's investigation ended with little evidence on price-fixing by limiting the supply of seats in January 2017 (McLaughlin and Schlangenstein, 2017). Meanwhile, Southwest and American airlines agreed to pay $\$ 15$ million and $\$ 45$ million to settle the class action in 2017 and 2018, respectively (U.S. District Court District of Columbia, 2017, 2018). 
and tourists in the demand model, while Kennedy et al. (2017) only use data of largesized markets with at least 2 million population and adopt a simple nested logit demand model.

Our study is also related to the broader literature on the airline industry and collusion. Building upon the BLP structural framework, Berry et al. (2006) and Berry and Jia (2010) develop the empirical model that accounts for discrete types of consumers and estimate jointly the demand and cost parameters in the airline industry. Ciliberto and Williams (2014) extend this structural model by allowing for the number of overlapping markets served with competing firms to affect pricing behavior and find that multi-market contact facilitates tacit collusion in the airline industry. In this paper, we employ common ownership in the BLP structural framework and show that it can be an additional potential facilitator of tacit collusion.

Our study also shares a similar idea with the literature, which suggests that controlling shareholders who own multiple firms can incentivize the commonly-owned firms to act for their benefits even in contradiction to minority shareholder interests. Faccio et al. (2011) and García-Kuhnert et al. (2015) investigate whether large shareholders, who diversify away idiosyncratic risks through diversification demand firms individually to take riskier investments to maximize their portfolio profits. Park et al. (2018) discovered that affiliated firms within a business group make a merger decision in a way that most benefits controlling shareholders across firms.

This paper is organized as follows. Section 2 describes the data, Section 3 presents the model, Section 4 discusses the estimation results, and Section 5 concludes. The Appendix shows the results of the robustness analysis.

\section{Data}

To examine the effect of common ownership in the financial market on product market competition, we study the U.S. airline industry, which has been gaining growing attention over its common ownership. In its 2015-2017 investigation into fare collusion among the major U.S. airlines, the U.S. Department of Justice (DOJ) has indicated its concerns over the possibility that "airlines have been communicating strategy with each other through their major common shareholders" (McLaughlin and Schlangenstein, 2015b).

We use the data on the shareholdings and airline industry in the first quarter of 2009. As in Berry et al. (2006) and Berry and Jia (2010), a market is defined as a unidirectional pair of an origin and a destination airport, where its size is the geometric mean of the metropolitan statistical area (MSA) population of the end-point cities. 
한국증권학회지 제 48 권 5호 (2019)

Our dataset has 244,253 observations, 5,503 markets, and 16 airlines.2) The data allow for substantial market-level variations to identify demand and cost parameters.

\subsection{Airline Industry}

We compute market-product level characteristics in the airline industry using the Airline Origin and Destination Survey (DB1B) published by the U.S. Department of Transportation (DOT). The quarterly survey is on a 10 percent sample of airline tickets from the U.S. reporting carriers. Following Berry et al. (2006), we keep round-trip domestic itineraries with at most four flight segments. ${ }^{3)}$ We exclude tickets below $\$ 25$, above $\$ 2500$, and with multiple ticketing carriers or a surface sector. ${ }^{4)}$ As discussed in Berry and Jia (2010), records cluster around very similar fares and consumers are unlikely to consider them as differentiated products. Thus, we aggregate the records into a set of progressive fare bins conditioning on the market, ticketing carrier, and nonstop and connecting service.5)

$<$ Table 1> reports the summary statistics of the key variables in our dataset. The product-market specific average airfare price is around $\$ 423$, the average number of connections is 1.22 , and the average distance flown is about 2,833 miles. The sample carriers serve, on average, about 50 different routes at originating airports, and use their hub airports when flying between end-cities of markets in over $50 \%$ of travels. ${ }^{6}$ ) The average number of products and carriers are about 44 and 4 across markets. The average proportion of low-cost carriers (LCC) and itineraries with nonstop service is 19 and 32 percent, respectively. These figures are in the levels similar to those in Berry and Jia (2010), whose data construction method we follow closely.

2) The sample airlines include American (AA), Alaska (AS), JetBlue (B6), Continental (CO), Delta (DL), Frontier (F9), AirTran (FL), Allegiant (G4), Spirit (NK), Northwest (NW), Sun Country (SY), USA3000 (U5), United (UA), US Air (US), Southwest (WN), and Midwest (YX).

3) The International Air Transport Association defines a flight segment as the operation of a flight between the two points where passengers first board and land an aircraft. For example, a round-trip nonstop ticket between LA and NY is comprised of two segments.

4) A surface sector is the part of an itinerary traveled by other than air.

5) As in Berry and Jia (2010), we use the following set of fare bins: $\$ 20$ for tickets under $\$ 700$ (i.e., tickets above $\$ 300$ and below $\$ 320$ with the same itinerary and ticketing carrier are considered to be the same product), $\$ 50$ for tickets between $\$ 700$ and $\$ 1000$, and $\$ 100$ for tickets above $\$ 1000$.

6) Following Ciliberto and Williams (2014), the hub airports are Atlanta (DL), Charlotte (US), Chicago O'Hare (AA, UA), Cincinnati (DL), Dallas/Fort Worth (AA), Denver (UA), Detroit (DL), Houston (CO), Minneapolis (DL), Newark (CO), Philadelphia (US), and Phoenix (US). 
$\langle$ Table 1〉 Summary Statistics

\begin{tabular}{|c|c|c|c|c|c|}
\hline Variable & Source & Description & Mean & Median & $\mathrm{SD}$ \\
\hline \multicolumn{6}{|l|}{ Product-Market } \\
\hline level & DB1B & Roundtrip ticket price & 422.98 & 350.00 & 272.91 \\
\hline Fare & DB1B & Number of connections & 1.22 & 2.00 & 0.98 \\
\hline Connection & DB1B & $\begin{array}{l}\text { Number of markets served by a } \\
\text { carrier at originating airports }\end{array}$ & 49.91 & 50.00 & 14.39 \\
\hline Market Coverage & DB1B & Miles flown & $2,833.26$ & $2,598.00$ & $1,573.39$ \\
\hline $\begin{array}{l}\text { Distance } \\
\text { Hub }\end{array}$ & DB1B & $\begin{array}{l}\text { Indicator that a carrier uses hub } \\
\text { airports between market cities }\end{array}$ & 0.52 & 1.00 & 0.50 \\
\hline \multicolumn{6}{|l|}{ Market level } \\
\hline Products & DB1B & Number of products & 44.39 & 35.00 & 36.80 \\
\hline Carriers & DB1B & Number of carriers & 4.48 & 5.00 & 2.30 \\
\hline $\mathrm{LCC}$ & DB1B & Proportion of low-cost carriers & 0.19 & 0.17 & 0.22 \\
\hline Direct & DB1B & Proportion of nonstop service & 0.32 & 0.14 & 0.36 \\
\hline Tour & Author & Indicator of tour airports & 0.11 & 0.00 & 0.31 \\
\hline \multirow[t]{2}{*}{ Market Size } & BEA & $\begin{array}{l}\text { Geometric mean of population at } \\
\text { market end cities (millions) }\end{array}$ & 3.50 & 2.68 & 2.47 \\
\hline & & & Total & & \\
\hline Markets & & & 5,503 & & \\
\hline Observations & & & 244,253 & & \\
\hline
\end{tabular}

\subsection{Common Ownership}

We construct the common ownership links among the airlines using institutional holdings data from the Thomson Reuters database of the U.S. Securities and Exchange Commission (SEC) $13 \mathrm{~F}$ filings.7) The data are quarterly and provide information on the U.S. equity holdings of institutional managers with at least $\$ 100$ million in equity assets under management. We complement it with non-institutional holdings data provided by Azar et al. (2018a), which were hand-collected from proxy statements in the SEC website for owners that hold at least $5 \%$ of outstanding shares.

$<$ Table 2> lists the six largest shareholders plus BlackRock and their ownership percentages of outstanding shares as of the first quarter of 2009 for publicly traded airline companies in our sample. The airline companies are owned partly by the same institutional investors. At the end of 2009, BlackRock acquired Barclays's fund management business (BGI) and the patterns in shareholdings became more concentrated.

7) Backus et al. (2019) argue that the Thomson Reuters dataset has gaps in coverage and errors relative to the source documents, the SEC $13 \mathrm{~F}$ filings. The discrepancy between the Thomson Reuters dataset and the scraped data of Backus et al. (2019) directly from the SEC 13F filings occurs in the period of 2010 and 2015. Since our analysis uses the data from the first quarter of 2009, it is relatively free from this data problem. 
한국증권학회지 제48권 5호 (2019)

This increasing trend in common ownership would continue because asset management companies are seeking for more market power amid the shift in demand towards cheaper passive index funds, and hence the number of mergers and acquisitions in the asset management industry are expected to grow (Moody's, 2018).

\section{〈Table 2〉 Share Holdings in 2009-Q1}

The table reports the six largest owners, BlackRock, and their corresponding holdings (in terms of percentages of outstanding shares) for publicly traded airline companies. The source of data on institutional holdings is the Thomson Reuters database of SEC 13F filings while that on non-institutional holdings is from Azar et al. (2018a) who hand-collected the data from the SEC website for owners that hold at least $5 \%$ of outstanding shares.

\begin{tabular}{|c|c|c|c|c|c|}
\hline \multicolumn{2}{|c|}{ American (AA) } & \multicolumn{2}{|c|}{ Alaska (AS) } & \multicolumn{2}{|c|}{ JetBlue (B6) } \\
\hline Fidelity & 13.87 & Primecap & 7.04 & Fidelity & 14.99 \\
\hline Primecap & 11.73 & DFA & 5.98 & Wellington & 6.28 \\
\hline ICC & 4.35 & Barclays & 5.74 & FII & 4.94 \\
\hline CWI & 3.61 & STT & 5.36 & Primecap & 4.17 \\
\hline Barclays & 3.55 & Fidelity & 5.10 & Barclays & 4.08 \\
\hline Vanguard & 3.38 & Franklin & 5.09 & Vanguard & 2.62 \\
\hline BlackRock & 0.13 & BlackRock & 0.35 & BlackRock & 1.23 \\
\hline \multicolumn{2}{|c|}{ Continental (CO) } & \multicolumn{2}{|l|}{ Delta (DL) } & \multicolumn{2}{|c|}{ Frontier $(\mathrm{FO})$} \\
\hline Fidelity & 10.41 & Fidelity & 14.84 & DFA & 9.89 \\
\hline Janus & 6.58 & Wellington & 11.11 & Greenlight & 9.82 \\
\hline Barclays & 3.85 & Lord Abbett & 10.21 & Fidelity & 6.33 \\
\hline Riversource & 3.39 & Wayzata & 4.95 & RoyCap & 6.15 \\
\hline Vanguard & 3.18 & J.P. Morgan & 4.23 & Barclays & 5.17 \\
\hline GMT & 3.00 & Vanguard & 2.92 & Wexford & 5.14 \\
\hline BlackRock & 0.13 & BlackRock & 1.47 & BlackRock & 0.49 \\
\hline \multicolumn{2}{|c|}{ AirTran (FL) } & \multicolumn{2}{|c|}{ Allegiant $(\mathrm{G} 4)$} & \multicolumn{2}{|c|}{ United (UA) } \\
\hline PAR & 10.11 & PAR & 20.56 & MFC Global & 9.89 \\
\hline Fidelity & 6.36 & Fidelity & 13.42 & Fidelity & 8.42 \\
\hline Goldman Sachs & 5.67 & Wellington & 7.20 & $\mathrm{BOA}$ & 5.87 \\
\hline Barclays & 5.64 & Franklin & 5.65 & CWI & 5.07 \\
\hline Alger & 5.05 & William Blair & 4.97 & Barclays & 4.97 \\
\hline Wellington & 4.05 & Water Street & 3.36 & AXA & 4.85 \\
\hline BlackRock & 1.29 & BlackRock & 0.17 & BlackRock & 0.24 \\
\hline \multicolumn{2}{|c|}{$\begin{array}{l}\text { US Air (US) } \\
\end{array}$} & \multicolumn{2}{|c|}{ Southwest (WN) } & & \\
\hline Fidelity & 13.74 & CRGI & 10.56 & & \\
\hline Wellington & 8.39 & T. Rowe Price & 9.37 & & \\
\hline Riversource & 6.66 & Primecap & 9.11 & & \\
\hline Barclays & 4.56 & Manning \& Napier & 6.30 & & \\
\hline Marathon & 3.58 & Barclays & 3.97 & & \\
\hline Vanguard & 3.40 & Vanguard & 3.28 & & \\
\hline BlackRock & 1.71 & BlackRock & 0.38 & & \\
\hline
\end{tabular}


MHHI delta is often used as a proxy variable of common ownership concentration in a reduced-form analysis; however, it lacks the theoretical background and causes an endogeneity problem. The MHHI delta is the part decomposed from the modified Herfindahl-Hirschman (MHHI) originated by Bresnahan and Salop (1986) and developed by O'brien and Salop (1999):

$$
\text { MHHI delta }=\sum_{j} \sum_{k} s_{j} s_{k} \frac{\sum_{i} \gamma_{i j} \beta_{i k}}{\sum_{i} \gamma_{i j} \beta_{i j}},
$$

where $s$ is the market share, $\gamma$ is the control weight, and $\beta$ is the total number of shares. The subscripts $i, j$ and $k$ index shareholder $i$, firm $j$, and firm $k$, respectively. Azar et al. (2018a) use this measure and analyze the anticompetitive effect of common ownership by regressing airfare prices on it. O'Brien and Waehrer (2017) criticize that the MHHI delta and state that it can bias the coefficient on common ownership because of its dependency on market share and the regression model is not well motivated by theory. Specifically, unobserved price factors can affect both prices and market shares, which results in a change in MHHI delta and accordingly an endogeneity problem.

In our analysis, instead of the MHHI delta, we use a term that is theoretically driven in the Bertrand-Nash pricing game and represents directly the anticompetitive incentive of shareholders with common ownership. Similar to O'Brien and Waehrer (2017) and Kennedy et al. (2017), we name the term "common ownership incentive" and define the common ownership incentive of firm $j$ with respect to firm $k$ as

$$
c_{j k}=\frac{\sum_{i} \gamma_{i j} \beta_{i k}}{\sum_{i} \gamma_{i j} \beta_{i j}}
$$

The common ownership incentive term does not depend on market shares, thereby mitigating the endogeneity problem. It also allows for pairwise variations across firms, which enables analysis at a more detailed level than the market level. Further details on the derivation are discussed in Section 3.2. <Table 3> presents the pairwise common ownership incentives as of the first quarter of 2009.8) The incentive is bigger when voting shareholders possess a larger number of ownership shares in competing firms.

8) We calculate the common ownership incentives in $\langle$ Table 3$\rangle$ given the assumption that a voting share guarantees an equal amount of control power. Thus, we use the number of voting shares as a proxy of the control weight $\gamma$ in (2). 
한국증권학회지 제48권 5호 (2019)

〈Table 3〉 Common Ownership Incentives in 2009-Q1

The off-diagonal numbers are the pairwise common ownership incentives calculated using (2). Each entry represents the degree of common ownership linkage faced by firm $i$ with respect to firm $j$. Refer to $\langle$ Table 2$\rangle$ for airline codes.

\begin{tabular}{|c|c|c|c|c|c|c|c|c|c|c|c|}
\hline $\mathrm{i}^{\mathrm{j}}$ & $\mathrm{AA}$ & AS & B6 & $\mathrm{CO}$ & DL & F9 & $\mathrm{FL}$ & G4 & UA & US & $\mathrm{WN}$ \\
\hline $\mathrm{AA}$ & & 0.573 & 0.302 & 0.352 & 0.231 & 0.214 & 0.237 & 0.153 & 0.428 & 0.335 & 0.884 \\
\hline AS & 0.295 & . & 0.383 & 0.355 & 0.214 & 0.669 & 0.430 & 0.387 & 0.416 & 0.273 & 0.524 \\
\hline B6 & 0.169 & 0.240 & & 0.097 & 0.213 & 0.151 & 0.171 & 0.155 & 0.113 & 0.194 & 0.161 \\
\hline $\mathrm{CO}$ & 0.236 & 0.440 & 0.232 & $\cdot$ & 0.186 & 0.303 & 0.252 & 0.173 & 0.688 & 0.204 & 0.451 \\
\hline DL & 0.132 & 0.167 & 0.273 & 0.135 & $\cdot$ & 0.090 & 0.195 & 0.246 & 0.175 & 0.319 & 0.193 \\
\hline F9 & 0.134 & 0.339 & 0.210 & 0.157 & 0.144 & $\cdot$ & 0.243 & 0.141 & 0.163 & 0.185 & 0.124 \\
\hline FL & 0.094 & 0.266 & 0.179 & 0.111 & 0.135 & 0.260 & & 0.861 & 0.195 & 0.178 & 0.136 \\
\hline G4 & 0.014 & 0.048 & 0.048 & 0.018 & 0.068 & 0.022 & 0.213 & · & 0.016 & 0.058 & 0.020 \\
\hline UA & 0.226 & 0.297 & 0.146 & 0.410 & 0.159 & 0.177 & 0.235 & 0.086 & $\cdot$ & 0.127 & 0.443 \\
\hline US & 0.364 & 0.450 & 0.538 & 0.235 & 0.717 & 0.411 & 0.535 & 0.464 & 0.298 & 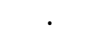 & 0.302 \\
\hline WN & 0.453 & 0.490 & 0.274 & 0.290 & 0.200 & 0.255 & 0.242 & 0.177 & 0.351 & 0.206 & \\
\hline
\end{tabular}

\section{Model}

We consider an oligopoly model where firms offer a set of differentiated products and compete on prices and allow common ownership across the firms to be taken into account in profit maximization. This structural framework is in the spirit of BLP, and the demand model is a discrete-type random-coefficient nested logit model that has been applied in a number of recent empirical studies on the U.S. airline industry Berry et al. (2006), Berry and Jia (2010), Ciliberto and Williams (2014). The supply model is modified to reflect the incentive to coordinate on prices with competitors due to common ownership. A similar setup for the ownership structure matrix has been used previously in Ciliberto and Williams (2014), Miller and Weinberg (2017), and Kennedy et al. (2017).

\subsection{Demand}

We assume a nested logit model for a consumer's choice behavior. We also assume heterogeneous consumers, where there are $\kappa_{r}$ proportions of type $r$ consumers. For a product of firm $j$ in market $t$, the utility of consumer $h$ of type $r$ is given by

$$
u_{h j t}^{r}=x_{j t} \beta_{r}-p_{j t} \alpha_{r}+\xi_{j t}+v(\lambda)_{h t}+\varepsilon_{h j t},
$$

where $x_{j t}$ is a vector of observed product characteristics, $p_{j t}$ is the price, $\left(\beta_{r}, \alpha_{r}\right)$ are the type $r$ consumer-specific taste parameters, $\xi_{j t}$ are unobserved product characte- 
ristics, $v_{h t}$ is a nested logit random taste constant across inside goods, $\lambda$ is the nested logit parameter, and $\varepsilon_{h j t}$ is an independently and identically distributed logit error. Two nests exist: one is for air-travel inside goods and the other is for the outside option of not buying any of the inside goods. The nested logit parameter, $\lambda \in[0,1]$, governs substitution patterns between the two nests. The mean utility of the outside option is normalized to zero.

The proportion of type $r$ consumers who choose to purchase a product from the airtravel nest is known to be

$$
\frac{D_{r t}^{\lambda}}{1+D_{r t}^{\lambda}}
$$

where $D_{r t}=\sum_{j} e^{\left(x_{j t} \beta_{r}-\alpha_{r} P_{j t}+\xi_{j t}\right) / \lambda}$. Conditional on purchasing the air-travel nest, the probability of type $r$ consumers choosing product $j$ in market $t$ is

$$
\frac{e^{\left(x_{j t} \beta_{r}-\alpha_{r} p_{j t}+\xi_{j t}\right) / \lambda}}{D_{r t}} \text {. }
$$

Then, the market share of product $j$ in market $t$ is

$$
S_{j t}\left(x, p, \xi ; \theta_{d}\right)=\sum_{r} \kappa_{r} \frac{e^{\left(x_{j t} \beta_{r}-\alpha_{r} P_{j t}+\xi_{j t}\right) / \lambda}}{D_{t}} \frac{D_{r t}^{\lambda}}{1+D_{r t}^{\lambda}} .
$$

\subsection{Pricing and Marginal Cost}

As in Azar et al. (2018a) and Kennedy et al. (2017), suppose a market is comprised of $N$ firms owned by $M$ shareholders. Each firm chooses its price to maximize the portfolio profits of the shareholders weighted by their control power.9) If a voting share guarantees an equal amount of control power, the profit maximization problem of firm $j$ is

$$
\max _{p_{j}} \sum_{i=1}^{M} \gamma_{i j} \pi^{i}
$$

9) Azar et al. (2018a) adopt a Cournot setting while Kennedy et al. (2017) take a Bertrand setting. Following the previous literature that structurally estimates demand and supply in the U.S. airline industry (e.g., Berry et al., 2006; Berry and Jia, 2010; Ciliberto and Williams, 2014), we assume price competition among airline companies. 
where $p_{j}$ is the product price of firm $j, \gamma_{i j}$ is the number of shares of firm $j$ with voting power exercised by shareholder $i$, and $\pi^{i}$ is the portfolio profit of shareholder $i$. This can be rewritten as

$$
\begin{gathered}
\max _{p_{j}} \sum_{i=1}^{M} \gamma_{i j} \sum_{k=1}^{N} \beta_{i k} S_{k}(p)\left(p_{k}-m c_{k}\right) \\
\propto S_{j}(p)\left(p_{j}-m c_{j}\right)+\sum_{\forall k \neq j} \frac{\sum_{i} \gamma_{i j} \beta_{i k}}{\sum_{i} \gamma_{i j} \beta_{i j}} S_{k}(p)\left(p_{k}-m c_{k}\right),
\end{gathered}
$$

where $\beta_{i j}$ is the total number of shares of firm $j$ accruing to shareholder $i$, and $S_{j}(p)$ and $m c_{j}$ are the market share and marginal cost of firm $j$, respectively. The subscript $k$ indexes firm $k$. The common ownership incentive in (8), $\frac{\sum_{i} \gamma_{i j} \beta_{i k}}{\sum_{i} \gamma_{i j} \beta_{i j}}$, measures the extent that firm $j$ is connected to firm $k$ through common ownership of their voting shareholders, which reflects the intensity of the anti-competitive incentive due to this connection.

For our empirical analysis, we consider the following problem of firm $j$ in which the "coordination weight" that a firm places upon its competitor is a function of the common ownership incentive:

$$
\max _{p_{j}} S_{j}(p)\left(p_{j}-m c_{j}\right)+\sum_{\forall k \neq j} f\left(c_{j k}\right) S_{k}(p)\left(p_{k}-m c_{k}\right),
$$

where $c_{j k}$ denotes the common ownership incentive, which is equal to $\frac{\sum_{i} \gamma_{i j} \beta_{i k}}{\sum_{i} \gamma_{i j} \beta_{i j}}$, and $f\left(c_{j k}\right)$ is the coordination weight that firm $j$ puts on firm $k$. The coordination weight determines how much a firm internalizes its price effect on the competitor's profit because of the overlapping shareholder and therefore captures the effect of the common ownership incentive on the price coordination.

The Bertrand-Nash pricing assumption generates the following optimality condition:

$$
\frac{\partial S_{j}}{\partial p_{j}}\left(p_{j}-m c_{j}\right)+S_{j}+\sum_{\forall k \neq j} f\left(c_{j k}\right) \frac{\partial S_{k}}{\partial p_{j}}\left(p_{k}-m c_{k}\right)=0
$$

The optimality condition implies a markup equation given by 


$$
p_{j}-m c_{j}=-\frac{S_{j}}{\frac{\partial S_{j}}{\partial p_{j}}}-\sum_{\forall k \neq j} f\left(c_{j k}\right) \frac{\frac{\partial S_{k}}{\partial p_{i}}\left(p_{k}-m c_{k}\right)}{\frac{\partial S_{j}}{\partial p_{j}}} .
$$

The markup of firm $j$ is not only determined by the own-price elasticity of demand but also by the degree of price coordination and the cross-price elasticity of demand. The last term of (11) is the additional markup attainable through coordination with other commonly owned firms. The size of additional markup gets bigger when firms care more about common ownership of voting shareholders in their pricing and the cross-price elasticity of demand with respect to the commonly owned firms is larger. If a firm sells a set of multiple products, the right-hand side of (11) includes another markup term achievable by the internalization of price effects on the other products within the same set.

Following BLP, we specify the marginal cost function as

$$
m c_{j t}=w_{j t} \varphi+\omega_{j t},
$$

where $w_{j t}$ is a vector of observed cost shifters, $\varphi$ is a vector of cost parameters, and $\omega_{j t}$ is an unobserved cost shock.

Equations (11) and (12) imply that the cost-side unobservable is

$$
\omega_{j t}=p_{j t}-b_{j t}\left(x, p, S ; \theta_{d}\right)-w_{j t} \varphi,
$$

where $b_{j t}$ is the model-implied markup.

\subsection{Estimation}

In the demand model, we consider two types of consumers: tourists and business travelers. The demand for flight itineraries are affected by the following set of observed product characteristics: airfare prices (Fare), number of connections (Connection), number of markets served by airlines at originating airports (Market Coverage), and distance flown (Distance). Unobservable attributes that influence a consumer's choice also exist, such as airline reputation and tourist places, which are partly controlled by the tour dummies for markets that cover Florida and Las Vegas (Tour) and carrier dummies. Among these variables, we consider three type-specific demand coefficients on Fare, Connection, and a constant.

In the supply model, we assume that marginal costs differ depending on airplane size following Berry and Jia (2010). Airplane size is proxied by the route-level dis- 
tance: the small- and medium-sized airplanes for markets shorter than 1,500 miles and the large-sized airplanes for markets longer than 1,500 miles. We consider the following set of cost shifters: Connection, Distance, and a constant. The availability of hub airports (Hub) also affects costs, and we include it in the empirical model.

Given the set of prices and observed product characteristics and conditional on parameters, we first invert (6) and solve for the vector of demand unobservables $\xi$ using the contraction mapping algorithm introduced in Berry et al. (2006), which is a modified version of Berry et al. (1995). For each candidate of demand parameters $\theta_{d}$, we evaluate the following equation until $\xi^{T}$ converges to $\xi$ and therefore the modelimplied market shares $S\left(x, p, \xi ; \theta_{d}\right)$ are equal to the actual observed market shares $s$. The iteration is expressed as

$$
\xi^{T}=\xi^{T-1}+\left[\ln s-\ln S\left(x, p, s ; \theta_{d}\right)\right],
$$

where $T$ denotes the $T$ th iteration. Then, the demand unobservable is a nonlinear function of the product characteristics, prices, observed market shares, and parameters:

$$
\xi=S^{-1}\left(x, p, s ; \theta_{d}\right)
$$

Next, we estimate the demand and cost parameters jointly by minimizing

$$
Q\left(\theta_{d}, \theta_{s}\right)=G\left(\theta_{d}, \theta_{s}\right)^{\prime} W^{-1} G\left(\theta_{d}, \theta_{s}\right)
$$

where $W$ is a weighting matrix, and $G\left(\theta_{d}, \theta_{s}\right)$ is the stacked set of the sample analogs of the population moments, $\left(g_{d}, g_{s}\right)$. The population moments are the orthogonality conditions between structural errors and instruments $z: g_{d}=E\left[\xi_{j t}\left(x, p, S ; \theta_{d}\right) \mid z_{j t}^{d}\right]=0$ and $g_{s}=E\left[\omega_{j t}\left(x, p, S ; \theta_{d}, \theta_{s}\right) \mid z_{j t}^{S}\right]=0$ for the demand and supply models, respectively.

The functional form of the coordination weight that we use in the estimation is

$$
f\left(c_{j k}\right)=\phi c_{j k},
$$

which is a linear function of the common ownership incentive similar to Kennedy et al. (2017). If the common ownership coefficient $\phi$ equals to 0 , we assume that the effect of common ownership on product market competition does not exist. Whereas, if $\phi$ is set to 1, we assume that firms take into account the common ownership incentive fully in their price setting as implied in the model under the assumption that one vote has one unit of control power. In the main model specification, we allow $\phi$ 
to be flexible between - 1 and 1 to consider the intermediate case of no effect and additionally full effect. We also allow $\phi$ to be negative to include the possibility that firms place a penalty on common ownership. A significantly positive coefficient on common ownership suggests a corporate decision is affected by common ownership of voting shareholders, which may result in price coordination among commonly owned firms and reduce the degree of product market competition.

Identification requires at least one instrument for endogenous and nonlinear parameters that satisfy the orthogonality with respect to structural errors. Prices are likely to be correlated with demand structural errors because firms acknowledge the value of the product characteristics unobserved by econometricians and reflect the value in prices. To deal with this endogeneity problem, we use a set of instruments that affect costs solely such as the hubness of the destination airports, which reduces the marginal cost of a flight by improving fuel efficiency but likely does not influence demand (Berry and Jia, 2010). We also include rival attributes such as the number of rival routes, the number of rival routes with direct flight service, etc. As for the nested logit parameter, we exploit the exogenous variation in the choice probability conditional on the purchase of the air-travel nest. The standard instrument is the number of firms operating in the market. We identify the discrete-type randomcoefficient parameters using the correlation between local demographics (e.g., population) and the exogenous observed product characteristics, which shows a different mix of products and different substitution patterns across markets. The common ownership incentives can be endogenous if the choice of shareholding is correlated with the unobserved cost shifters. Accordingly, we instrument them with the number of airlines with the index inclusion at the market level and use the information on the Russell 1000 following Kennedy et al. (2017). Finally, similar to Berry and Jia (2010), we include the exogenous variables in the share and marginal cost equations and interaction terms between the variables with low collinearity.

\section{Results}

The structural estimates from different model specifications on common ownership and price coordination are reported in $<$ Table $4>$.10) We consider three cases for the common ownership coefficient: (1) $\phi=0$, (2) $\phi=1$, (3) $|\phi| \leq 1$.

10) In Section 4, we discuss the main estimation results using the data of 2009Q1. In the Appendix, we analyze a longer period, 2009Q1 to 2011Q4, and find that the results are consistent with the ones presented in Section 4. 


\section{〈Table 4〉Estimation Results}

The table reports the structural estimates of demand and supply models using data on airline tickets and shareholdings in the first quarter of 2009. The key variable of our interest is common ownership and its coefficient measures the extent to which the airlines incorporate their common ownership linkage into their pricing behavior. Carrier dummies are included in all regressions and their coefficient estimates are omitted. ${ }^{* * *}<0.01,{ }^{* *}<0.05,{ }^{*}<0.10$.

\begin{tabular}{|c|c|c|c|c|c|c|}
\hline & \multicolumn{2}{|l|}{$\begin{array}{c}(1) \\
\phi=0\end{array}$} & \multicolumn{2}{|c|}{$\begin{array}{c}(2) \\
\phi=1\end{array}$} & \multicolumn{2}{|c|}{$\begin{array}{c}(3) \\
|\phi| \leq 1\end{array}$} \\
\hline & Estimate & SE & Estimate & SE & Estimate & SE \\
\hline \multicolumn{7}{|l|}{ A. Demand variables } \\
\hline Fare $_{1}$ & $-0.949^{* * *}$ & 0.037 & $-0.949^{* * *}$ & 0.037 & $-0.925^{* * *}$ & 0.035 \\
\hline Connection $_{1}$ & $-0.706^{* * *}$ & 0.016 & $-0.696^{* * *}$ & 0.016 & $-0.686^{* * *}$ & 0.016 \\
\hline Constant $_{1}$ & $-11.619^{* * *}$ & 0.518 & $-11.523^{* * *}$ & 0.519 & $-11.408^{* * *}$ & 0.516 \\
\hline Fare $_{2}$ & $-0.067^{* * *}$ & 0.013 & $-0.066^{* * *}$ & 0.014 & $-0.066^{* * *}$ & 0.013 \\
\hline Connection $_{2}$ & $-0.459^{* * *}$ & 0.035 & $-0.478^{* * *}$ & 0.035 & $-0.490^{* * *}$ & 0.035 \\
\hline Constant $_{2}$ & $-14.880^{* * *}$ & 0.726 & $-14.710^{* * *}$ & 0.736 & $-14.420^{* * * *}$ & 0.728 \\
\hline Market coverage & $0.164^{* * *}$ & 0.003 & $0.165^{* * *}$ & 0.003 & $0.164^{* * *}$ & 0.003 \\
\hline Distance & $1.029^{* * *}$ & 0.151 & $1.002^{* * *}$ & 0.151 & $0.953^{* * *}$ & 0.149 \\
\hline Distance $^{2}$ & $-0.049^{* * *}$ & 0.010 & $-0.047^{* * *}$ & 0.010 & $-0.044^{* * *}$ & 0.010 \\
\hline Tour & $0.373^{* * *}$ & 0.007 & $0.376^{* * *}$ & 0.007 & $0.376^{* * *}$ & 0.007 \\
\hline$\lambda$ & $0.646^{* * *}$ & 0.001 & $0.643^{* * *}$ & 0.001 & $0.646^{* * *}$ & 0.001 \\
\hline$\kappa$ & $0.855^{* * *}$ & 0.029 & $0.862^{* * *}$ & 0.028 & $0.869^{* * *}$ & 0.026 \\
\hline \multicolumn{7}{|l|}{ B. Cost variables } \\
\hline Constant $_{\text {short }}$ & $1.489^{* * *}$ & 0.052 & $1.373^{* * *}$ & 0.056 & $1.380^{* * *}$ & 0.062 \\
\hline Distance $_{\text {short }}$ & $0.510^{* * *}$ & 0.020 & $0.471^{* * *}$ & 0.020 & $0.480^{* * *}$ & 0.021 \\
\hline Connection $_{\text {short }}$ & -0.007 & 0.008 & 0.001 & 0.008 & -0.002 & 0.008 \\
\hline Constant $_{\text {long }}$ & $2.093^{* * *}$ & 0.048 & $1.944^{* * *}$ & 0.054 & $1.953^{* * *}$ & 0.062 \\
\hline Distance $_{\text {long }}$ & $0.123^{* * *}$ & 0.004 & $0.108^{* * *}$ & 0.004 & $0.116^{* * *}$ & 0.005 \\
\hline Connection long $_{1}$ & $-0.062^{* * *}$ & 0.007 & $-0.048^{* * *}$ & 0.007 & $-0.052^{* * *}$ & 0.007 \\
\hline Hub & $-0.207^{* * *}$ & 0.018 & $-0.169^{* * *}$ & 0.017 & $-0.168^{* * *}$ & 0.019 \\
\hline \multicolumn{7}{|l|}{ C. Conduct variable } \\
\hline Common Ownership $(\phi)$ & & & & & $0.970^{* * *}$ & 0.253 \\
\hline \multicolumn{7}{|l|}{ D. Model fit } \\
\hline Median marginal cost & 2.176 & & 2.120 & & 2.117 & \\
\hline Median elasticity & -3.461 & & -3.293 & & -3.398 & \\
\hline Median elas. - type 1 & -5.136 & & -5.163 & & -5.002 & \\
\hline Median elas. - type 2 & -0.362 & & -0.357 & & -0.358 & \\
\hline$N$ & 244,253 & & 244,253 & & 244,253 & \\
\hline
\end{tabular}

Column 1 of <Table $4>$ presents the estimates of the demand and marginal costs when we assume that firms compete as Bertrand-Nash competitors and do not coordinate on prices. In this case, $\phi$ is restricted to 0 and therefore firms are not influ- 
enced by common ownership of voting shares when they are choosing prices. The estimates are all in the expected signs and are largely consistent with previous studies of the airline industry (e.g., Berry et al., 2006; Berry and Jia, 2010; Ciliberto and Williams, 2014). We find that the price coefficients are -0.949 for the first type and -0.067 for the second type. The fraction of the first type (к) is 0.855 . From this result, we can infer that the first type is the tourist type who is very sensitive to prices and takes a larger fraction of the total consumers. The second type is, then, the business-traveler type. The median own-price elasticities of demand ${ }^{11)}$ are -5.136 for the tourist type and -0.362 for the business-traveler type, which makes -3.461 in total. As expected, consumers prefer direct flight services and airlines that serve diverse markets from originating airports. The concave relationship in distance flown shows consumers find air travel more attractive for trips with long distance but this effect diminishes gradually as the outside option of no air travel becomes more attractive. The nested logit parameter $(\lambda)$ is 0.646 , thereby suggesting that substitution patterns occur within the air-travel nest. On the supply side, we find that the marginal cost is increasing in distance, and decreasing in the number of connections and availability of hub airports.

Column 2 of <Table $4>$ shows the results when we assume that $\phi$ equals to 1 and the degree of price coordination is determined exactly by the common ownership incentives. As in Ciliberto and Williams (2014), we find that the demand estimates are similar whereas the supply estimates differ from that in Column 1 of $<$ Table $4>$ in response to a change in the assumed behavioral model. The differences in the estimated coefficients and assumption on the effect of common ownership lead to slightly different estimates of marginal costs and elasticities.

Column 3 of $<$ Table $4>$ presents the estimates of the main model specification including the coefficient on common ownership incentives and demand and marginal costs. In this case, we allow $\phi$ to be flexible between -1 and 1 to enable firms to reflect common ownership incentives only partially or even negatively in their pricing behavior. We find that the coefficient on common ownership incentives is significantly positive. The result implies that airline companies are controlled by their voting shareholders and internalize their price effect on the profits of commonly owned companies. Therefore, common ownership in the financial market is likely to have facilitated price coordination and raised airfare prices in the U.S. airline industry in the first quarter of 2009. The magnitude of the estimate is 0.970 , which suggests the weights that firms put on other firms in the profit maximization problem are almost

11) The derivative of demand (or market share) with respect to price is computed from (6) and the demand estimates in $\langle$ Table 4$\rangle$. 
equal to the size of common ownership incentives. In the presence of this nonzero coefficient on common ownership incentives, most demand and supply estimates except for the type 1 fraction are slightly lower than the ones in Columns 1 and 2 of $<$ Table $4>$. The price coefficients are -0.925 for the tourist type and -0.066 for the business-traveler type with the tourist-type ratio of 0.869 , which leads to a median marginal cost of $\$ 211.7$, the median own-price elasticity of -5.002 for the tourist type and -0.358 for the business-traveler type.

$<$ Table $5>$ provides the coordination weights conditional on the estimates in $<$ Table $4>$ and given the common ownership incentives in $<$ Table $3>$ as of the first quarter of 2009. The weights represent the extent to which a firm internalizes its price effect on the profits of its rivals because of the presence of common ownership. The highest value of the common ownership incentives is 0.884 , leading to a coordination weight of 0.858 that American Airlines (AA) places on Southwest Airlines (WN). The result indicates that voting shareholders of AA have large common ownership in WN and have anticompetitive incentives to maximize their aggregate profits, which results in large coordination weight for AA with respect to WN. Among the publicly traded airline companies, the lowest common ownership incentive and corresponding coordination weight are 0.014 for Allegiant Air (G4) with respect to AA.

〈Table 5> Coordination Weights in 2009-Q1

The off-diagonal numbers are the coordination weights computed according to (17) using the common ownership incentives in 〈Table 3$\rangle$ and the estimate of the common ownership coefficient in $\langle$ Table 4$\rangle$. Each entry represents the degree to which firm $i$ internalizes its price effect on the profit of firm $j$. Refer to $\langle$ Table 2$\rangle$ for airline codes.

\begin{tabular}{lccccccccccc}
\hline i & AA & AS & B6 & CO & DL & F9 & FL & G4 & UA & US & WN \\
\hline AA & $\cdot$ & 0.556 & 0.293 & 0.341 & 0.224 & 0.207 & 0.230 & 0.148 & 0.416 & 0.325 & 0.858 \\
AS & 0.286 & $\cdot$ & 0.372 & 0.345 & 0.208 & 0.649 & 0.418 & 0.376 & 0.404 & 0.265 & 0.509 \\
B6 & 0.164 & 0.233 & $\cdot$ & 0.094 & 0.207 & 0.146 & 0.166 & 0.151 & 0.110 & 0.188 & 0.156 \\
CO & 0.229 & 0.426 & 0.225 & $\cdot$ & 0.180 & 0.294 & 0.244 & 0.168 & 0.668 & 0.198 & 0.437 \\
DL & 0.128 & 0.162 & 0.265 & 0.131 & $\cdot$ & 0.087 & 0.189 & 0.239 & 0.170 & 0.310 & 0.187 \\
F9 & 0.130 & 0.329 & 0.204 & 0.152 & 0.139 & & 0.236 & 0.137 & 0.158 & 0.180 & 0.120 \\
FL & 0.092 & 0.258 & 0.173 & 0.108 & 0.131 & 0.252 &. & 0.835 & 0.189 & 0.173 & 0.132 \\
G4 & 0.014 & 0.047 & 0.047 & 0.017 & 0.066 & 0.022 & 0.207 & $\cdot$ & 0.016 & 0.056 & 0.019 \\
UA & 0.219 & 0.288 & 0.142 & 0.398 & 0.154 & 0.171 & 0.228 & 0.083 & $\cdot$ & 0.123 & 0.430 \\
US & 0.353 & 0.437 & 0.522 & 0.228 & 0.695 & 0.399 & 0.519 & 0.450 & 0.289 & $\cdot$ & 0.293 \\
WN & 0.439 & 0.476 & 0.266 & 0.281 & 0.194 & 0.248 & 0.235 & 0.171 & 0.341 & 0.200 & $\cdot$ \\
\hline
\end{tabular}

The results in the main model specification suggest that airline companies linked through higher common ownership are more likely to coordinate to a larger degree in setting airfare prices. In turn, this coordination could channel into prices higher than 
the competitive levels, which has a negative effect on the market competitiveness. Our finding is largely consistent with Azar et al. (2018a), who show that common ownership increases prices in the U.S. airline industry using the reduced-form regression model, and are related closely to He and Huang (2017), who reveal that common ownership increases corporate profitability using the U.S. industry data including those of airlines. Meanwhile, our finding is in contrast with that of Kennedy et al. (2017), who argue that airline companies do not take into account their shareholders' common ownership in setting prices using the structural model.12) Although the structural model of Kennedy et al. (2017) is similar to the one we use in this study, two main differences can be observed. First, they select only large-sized markets with at least 2 million population and use a limited dataset in their analysis. Second, they estimate demand with a simple nested logit model and a smaller set of control variables. In contrast, we use data from medium to large areas with at least 0.85 million population following Berry and Jia (2010). Berry and Jia (2010) state that they exclude small markets that exhibit a "drastic difference" in demand patterns. However, the exclusion of medium markets, which account for the majority of the observations, appears to limit the cross-sectional variation and change the estimation result. Further, we allow for heterogeneous taste across different consumer types to obtain more realistic patterns of elasticities, which in turn affects the supplyside cost estimates. We also consider a larger set of observed product characteristics and cost shifters to control for possible confounding factors that might affect the statistical relationship of our interest. These contrasting features led to our conclusion on the anticompetitive effect of common ownership.

\section{Conclusion}

We find that common ownership softened the competition in the U.S. airline industry. In particular, we adopt a structural model of demand and supply and use an additional instrument for common ownership to overcome the endogeneity problem. We identify the extent to which airlines are controlled by the anti-competitive incentive

12) Kennedy etal. (2017) find that the coefficient of common ownership is insignificant, which however does not reject the hypothesis that common ownership has a positive effect on prices nor does it provide any evidence on the relationship between common ownership and market competition. A part of their estimation results including the negative effect of distance on marginal costs contradicts economic logic and is inconsistent with previous literature such as Berry and Jia (2010) and Ciliberto and Williams (2014). Azar et al. (2018b) argue that this finding indicates the possibility of inadequate data construction and model misspecification, which might have led to such inconclusive result. 
of voting shareholders and consider common ownership linkage when setting airfare prices. The results suggest airlines with a significant level of common ownership linkage (e.g. American and Southwest) internalize their price effects on the profits of commonly owned firms and coordinate on prices by a larger degree, whereas those with little common connection (e.g., Allegiant and American) do not.

One possible extension of this paper would be a merger analysis that accounts for the effects of common ownership on product markets. Generally, mergers and acquisitions should meet antitrust approval. For example, BlackRock's acquisition of BGI was allowed after assessments on its anticompetitive effect in the asset management industry (Commission of the European Communities, 2009). However, such a change alters the ownership structure in other product markets that related asset managers hold shares, which in turn could affect the degree of competitiveness in the markets. In such a case, the antitrust merger review process should include assessments on the counterfactual common ownership level and its effects on product market competition. 


\section{References}

Azar, J., Portfolio diversification, market power, and the theory of the firm, Market Power, and the Theory of the Firm (August 23, 2017), 2017.

Azar, J., S. Raina, and M. C. Schmalz, Ultimate ownership and bank competition, Available at SSRN 2710252, 2016.

Azar, J., M. C. Schmalz, and I. Tecu, 2018a, Anticompetitive effects of common ownership, The Journal of Finance, Vol. 73 (4), pp. 1513-1565.

Azar, J., M. C. Schmalz, and I. Tecu, The competitive effects of common ownership: Economic foundations and empirical evidence: Reply, Available at SSRN 3044908, $2018 \mathrm{~b}$.

Backus, M., C. Conlon, and M. Sinkinson, Common ownership and competition in the ready-to-eat cereal industry, Working Paper, New York University Stern, 2018.

Backus, M., C. Conlon, and M. Sinkinson, Common ownership in America: 1980-2017, Technical Report, National Bureau of Economic Research, 2019.

Berry, S., M. Carnall, and P. T. Spiller, Airline hubs: Costs, markups and the implications of customer heterogeneity, Competition Policy and Antitrust, 2006.

Berry, S., and P. Jia, 2010, Tracing the woes: An empirical analysis of the airline industry, American Economic Journal: Microeconomics, Vol. 2 (3), pp. 1-43.

Berry, S., J. Levinsohn, and A. Pakes, 1995, Automobile prices in market equilibrium, Econometrica: Journal of the Econometric Society, Vol. 63 (4), pp. 841-890.

Bresnahan, T. F., and S. C. Salop, 1986, Quantifying the competitive effects of production joint ventures, International Journal of Industrial Organization, Vol. 4 (2), pp. 155-175.

Ciliberto, F., and J. W. Williams, 2014, Does multimarket contact facilitate tacit collusion? inference on conduct parameters in the airline industry, The RAND Journal of Economics, Vol. 45 (4), pp. 764-791.

Commission of the European Communities, Case No COMP/M. 5580-BlackRock/Barclays Global Investors UK Holdings Notification of 18 August 2009 pursuant to Article 4 of Council Regulation (EC) No 139/2004, 2009.

Faccio, M., M.-T. Marchica, and R. Mura, 2011, Large shareholder diversification and corporate risk-taking, The Review of Financial Studies, Vol. 24 (11), pp. 36013641.

García-Kuhnert, Y., M.-T. Marchica, and R. Mura, 2015, Shareholder diversification and bank risk-taking, Journal of Financial Intermediation, Vol. 24 (4), pp. 602635. 
한국증권학회지 제 48 권 5호 (2019)

Gramlich, J., and S. Grundl, Estimating the competitive effects of common ownership, FEDS Working Paper 2017-029, 2017.

Hansen, R. G., and J. R. Lott, 1996, Externalities and corporate objectives in a world with diversified shareholder/consumers, Journal of Financial and Quantitative Analysis, Vol. 31 (1), pp. 43-68.

He, J. J., and J. Huang, 2017, Product market competition in a world of crossownership: Evidence from institutional blockholdings, The Review of Financial Studies, Vol. 30 (8), pp. 2674-2718.

Kennedy, P., D. P. O'Brien, M. Song, and K. Waehrer, The competitive effects of common ownership: Economic foundations and empirical evidence, Working Paper 3008331, SSRN online, 2017.

McLaughlin, D., and M. Schlangenstein, U.S. airlines face an antitrust probe into possible collusion, Bloomberg Business, 2015a.

McLaughlin, D., and M. Schlangenstein, U.S. looks at airline investors for evidence of fare collusion, Bloomberg Business, 2015b.

McLaughlin, D., and M. Schlangenstein, U.S. airlines unlikely to face an antitrust case on capacity, Bloomberg Business, 2017.

Miller, N. H., and M. C. Weinberg, 2017, Understanding the price effects of the millercoors joint venture, Econometrica, Vol. 85 (6), pp. 1763-1791.

Moody's, Asset management - Global: 2019 outlook, 2018.

O'brien, D. P., and S. C. Salop, 1999, Competitive effects of partial ownership: Financial interest and corporate control, Antitrust LJ, Vol. 67, p. 559.

O'Brien, D. P., and K. Waehrer, The competitive effects of common ownership: We know less than we think, Available at SSRN 2922677, 2017.

Park, K. S., C. S. Jung, and S. M. Kim, 2018, Investors already know what controlling shareholders will do this summer: A study on the conflicts of interests between controlling shareholders and minority shareholders in affiliated mergers, Korean Journal of Financial Studies, Vol. 47 (5), pp. 741-777.

Rotemberg, J., Financial transaction costs and industrial performance, WP 1554-84, Sloan School of Management, MIT, 1984.

U.S. District Court District of Columbia, Settlement agreement between Plaintiffs and Southwest Airlines Co, 2017.

U.S. District Court District of Columbia, Memorandum in support of motion for preliminary approval of settlement with defendant American Airlines, Inc, 2018. 


\section{$<$ Appendix $>$}

\section{A. Robustness Analysis}

We investigate how demand and supply estimates are modified with the changes in the dataset and price aggregation method. Previously, we use one-quarter data and employ a series of progressive fare bins used by Berry and Jia (2010) to differentiate between the market-carrier level tickets. In this section, we use a larger set of data from 2009Q1 to 2011Q4 to exploit the time variation. We also aggregate tickets at the market-carrier level following Azar et al. (2018a) and Ciliberto and Williams (2014), and thus the market-carrier level tickets are treated as the same product.

$<$ Table A1> shows that the parameter estimates of demand and supply coefficients are consistent with the main estimation results. In particular, the coefficient on the key variable of our interest, common ownership, is significantly positive with a magnitude of 0.979 at a very similar level to the one estimated previously. The main conclusion on common ownership and its effect on market competition is stable across time and does not depend on a specific method of data aggregation.

\section{$\langle$ Table A1〉 Estimation Results}

The table reports the structural estimates of the demand and supply models using data on airline tickets and shareholdings in the period of 2009 2011. The number of observations is 444,983 . The key variable of our interest is common ownership and its coefficient measures the extent to which airlines incorporate common ownership linkage into pricing behavior. Carrier- and time-fixed effects are included and their coefficient estimates are omitted. ${ }^{* * *}<0.01,{ }^{* *}<0.05,{ }^{*}<0.10$.

\begin{tabular}{|c|c|c|c|c|c|}
\hline & Estimate & $\mathrm{SE}$ & & Estimate & $\mathrm{SE}$ \\
\hline A. Demand variables & & & B. Cost variables & & \\
\hline Fare $_{1}$ & $-1.165^{* * * *}$ & 0.027 & Constant $_{\text {short }}$ & $1.256^{* * *}$ & 0.022 \\
\hline Connection $_{1}$ & $-0.829^{* * *}$ & 0.011 & Distance $_{\text {short }}$ & $0.742^{* * *}$ & 0.014 \\
\hline Constant $_{1}$ & $-5.124^{* * *}$ & 0.064 & Connection $_{\text {short }}$ & $0.043^{* * *}$ & 0.004 \\
\hline $\mathrm{Fare}_{2}$ & $-0.114^{* * *}$ & 0.012 & Constant $_{\text {long }}$ & $2.013^{* * *}$ & 0.026 \\
\hline Connection $_{2}$ & $-0.993^{* * *}$ & 0.022 & Distance $_{\text {long }}$ & $0.168^{* * *}$ & 0.002 \\
\hline Constant $_{2}$ & $-6.646^{* * *}$ & 0.193 & Connection $_{\text {long }}$ & $0.032^{* * *}$ & 0.003 \\
\hline Market Coverage & $0.244^{* * *}$ & 0.002 & Hub & $-0.027^{* *}$ & 0.013 \\
\hline Distance & $0.333^{* * *}$ & 0.016 & C. Conduct variable & & \\
\hline Distance $^{2}$ & -0.011 & 0.011 & Common ownership $(\phi)$ & $0.979^{* * *}$ & 0.022 \\
\hline Tour & $0.251^{* * *}$ & 0.007 & D. Model fit & & \\
\hline$\lambda$ & $0.492^{* * * *}$ & 0.013 & Median marginal cost & 2.644 & \\
\hline$\kappa$ & $0.950^{* * *}$ & 0.025 & Median elasticity & -5.324 & \\
\hline
\end{tabular}

